\title{
GIS-Modeling of Island Hopping Through the Philippines Demonstrates Trade-Offs Migrant Grey-Faced Buzzards Face During Oceanic Crossings
}

\author{
Camille B. Concepcion ${ }^{1,2,3^{*}}$, Keith L. Bildstein ${ }^{2}$, Todd E. Katzner ${ }^{1,4,5}$ \\ ${ }^{1}$ Division of Forestry \& Natural Resources, West Virginia University, Morgantown WV 26506 USA \\ ${ }^{2}$ Hawk Mountain Sanctuary, 1700 Hawk Mountain Rd., Kempton, PA 19527 USA \\ ${ }^{3}$ Science Department, College of Natural Sciences and Mathematics, \\ Mindanao State University, Fatima, General Santos City 9500 Philippines \\ ${ }^{4}$ United States Department of Agriculture, Forest Service, \\ Timber and Watershed Laboratory, Parsons, West Virginia 26287, USA \\ ${ }^{5}$ U.S. Geological Survey, 970 Lusk St., Boise, ID 83706 USA \\ *Corresponding author: cbconcepcion@gmail.com
}

Received: December 7, 2019; Accepted: April 13, 2020

\begin{abstract}
Migration can be costly with consequences that can influence population trajectories. These costs and consequences are especially heightened during over-water travels, which can be high-risk events for birds. We created spatial models to evaluate potential migratory responses of "oceanic", island-hopping grey-faced buzzards that encounter variation in landscape parameters and weather as they move through and out of the Philippine archipelago. We constrained the modeled routes to enter the island chain at Basco and to use one of four potential exit points in the south of the country, either Balabac, Bongao, Balut Island, or Cape San Agustin. We used all possible combinations of our three external parameters (stopover sites, water crossings and wind direction) to model alternative migratory routes for each of the four exit points $(\mathrm{n}=20$ migratory routes). Modeled grey-faced buzzard routes were between 1,582 and 2,970 km. Routes overlapped over eastern and central Luzon, along a leading line created by the Sierra Madre Mountains. Routes also overlapped and suggested unavoidable over-water crossings between Mindoro and Palawan, Negros and Zamboanga del Norte, and Leyte and Surigao. Our models suggest that the optimal migratory strategy for these birds is to find the shortest route to an exit point with the greatest possible access to stopover habitats and fewest open-water crossings under wind resistance. Understanding how each of these external factors affected the geography and characteristics of the migratory routes helps us to understand the context for different migratory strategies of birds that face dangerous open-water crossings on migration.
\end{abstract}

Keywords: Grey-faced Buzzard, migration, optimal route, over-water crossing, Philippines

Migration can be a costly period that can influence regulation of bird populations through its consequences to survival and, in some cases, to reproduction [1,2]. Survival is lower during migration than during non-migratory periods $[3,4]$ and may vary by sex [3] or age [5]. The consequences of low survival and individual decisions made during migration and wintering in turn have important carry over effects on sex ratio dynamics and reproductive success [6-9]. These effects of migration often are influenced by the range of external conditions that migrants encounter as they move back and forth between breeding grounds and wintering grounds $[10,11]$. 
To account for these consequences, there is selective pressure to minimize costs associated with energy, time and risk on migration [12,13]. For example, although migration influences the energy balance of birds $[14,15]$, migrating raptors are able to reduce energetic costs by using soaring flight [16]. Soaring is fast [17] and so energy efficient [18] that soaring migrants can cover long distances with little or no need to refuel $[16,19]$.

Although soaring can help minimize energy and time, it does not however, reduce safety costs, or risks, associated with over-water travel. When making over-water crossings, the odds of success are much higher when weather conditions are favorable [20-23]. Decision lapses over-water are highly consequential because they may lead to fatigue and ultimately death [5,24]. Decision lapses also are especially common for young, inexperienced birds which are still honing navigation and orientation abilities $[25,26]$ and learning appropriate migratory responses to weather and the landscape they encounter [27,28]. As such, if young, inexperienced birds survive their first over-water crossings, they sometimes do so in spite of being blown off course by wind drift $[25,26]$, and following longer migration routes over extended migration periods [29,30]. Despite these challenges, over-water routes are often shorter and, with the assistance of supporting winds and appropriate soaring conditions [20, $31,32]$, may be a significant ecological corridor for birds adapted for such flight $[33,34]$.

The grey-faced buzzard, Butastur indicus, regularly completes long-distance, over-water travel and is considered to be one of the most "oceanic" of raptor migrants [16]. Every year, more than 10,000 grey-faced buzzards migrate across Taiwan before crossing at least $180 \mathrm{~km}$ of open ocean to reach the Philippines [35]. Once within the Philippine Archipelago, nearly all of them make multiple, short oceanic crossings while island-hopping through the country. Although some of them over-winter in the Philippines, others make another large ocean crossing, from the southern extent of the archipelago on Palawan and Mindanao to Borneo and Indonesia, $120 \mathrm{~km}$ further south [36]. Because their migration is both so oceanic and so observable at these few points of land arrival and departure, this species is a good model for understanding the causes and consequences of migration behavior over large expanses of water.

We built spatial models to assess costs, consequences and potential migratory responses of grey-faced buzzards to different external factors (e.g. weather conditions and landscape characteristics) and to provide insight into migratory strategies individuals may select along this East Asian Oceanic Flyway. Our models addressed two specific research questions: (a) how may autumn migration routes vary as a result of trade-offs in migratory response; and (b) how the choice of migration strategy may influence which potential exit points will be used as buzzards depart from the Philippines. We then interpret these outputs to provide insight into the relative costs and benefits to each migratory strategy and to other migrants that also make substantial ocean crossings.

\section{Materials and Methods}

\section{Study Area}

The Philippines is a tropical, southeast Asian archipelago made up of over 7,000 islands with a land area of $300,000 \mathrm{~km}^{2}$ (Figure 1). Land cover is a mosaic of rainforests, croplands and plantations [37]. The forests that have not been cleared for agriculture (i.e. lowland dipterocarp, high elevation montane, and mangroves) are found mostly in the northern and southern parts of the island of Luzon, and on the islands of Palawan and Mindanao. Natural grasslands have been converted primarily for agriculture and agro-forestry.

The Philippines belongs to the "Maritime Continent" [38] and experiences a monsoon-type climate, with high temperatures, high humidity and abundant rainfall throughout the year $[39,40]$. Mean annual temperature across the country is $25-28^{\circ} \mathrm{C}$. Average rainfall is between $1-4 \mathrm{~m}$ annually. The southwest monsoon and northeast monsoon alternate through the region in a seasonal cycle. From May to September, the southwest monsoon brings hot and humid weather and frequent rainfall as a result of warm, moist air $[39,41]$. This southwest monsoon brings rains to the western side of the Philippines. From October to late March, the northeast monsoon, dominated by trade winds, brings moderate temperatures and little or no rainfall as a result of cool winds. These minor northeast monsoon rains affect the eastern side of the Philippines. The Philippines also experiences cold fronts from November to February which increase cloudiness and can produce heavy rains nationwide.

\section{Focal Species}

The grey-faced buzzard is a small raptor 
that breeds in eastern-mainland Asia and winters in southern East Asia and parts of Pacific Asia [36]. Some grey-faced buzzards migrate to and winter in the Philippines whereas others migrate through and continue on to more southerly destinations. Greyfaced buzzards are believed to exhibit high fidelity to both migration routes and to stopover sites [42]. The species' passage has been suggested as a good indicator to identify important raptor migration watch sites [35].

The grey-faced buzzard occupies open habitat $[43,44]$, favoring farmlands sharing edges with forests or wooded areas $[45,46]$. Although it may use a wide range of farmlands, the grey-faced buzzard prefers to forage for frogs, lizards and grasshoppers in cultivated or wet rice paddy fields during both breeding and wintering season $[44,47,48]$. The wintering home range of greyfaced buzzards is 0.25 to $0.75 \mathrm{~km}^{2}$ [46]. Conversion of agricultural lands, particularly the abandonment of rice paddy fields, has led to a welldocumented and rapid decline in grey-faced buzzard breeding population in Japan $[49,50]$.

\section{Modeling Approach}

To provide a framework to understand why

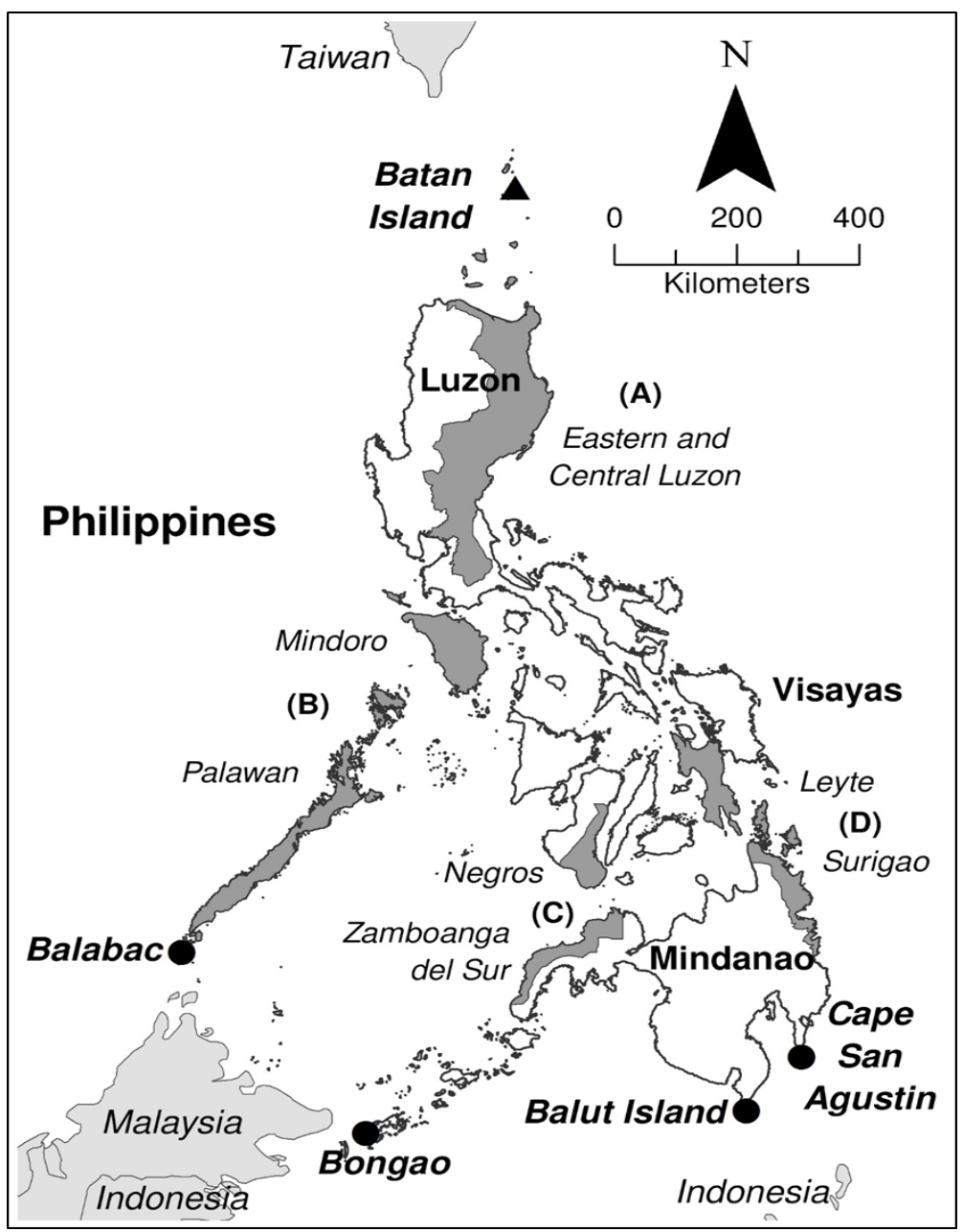

Figure 1. Geographic locations of migratory entry $(\boldsymbol{\Delta})$ and exit points $(\boldsymbol{O})$ in the Philippines. The Philippine archipelago is divided into three island groups: Luzon in the north, Visayas in the middle, and Mindanao in the south. The entry point of Basco is $180 \mathrm{~km}$ south of Taiwan and $280 \mathrm{~km}$ north of mainland Luzon. The exit point of Balabac is $70 \mathrm{~km}$ north of Borneo, while Bongao is $60 \mathrm{~km}$ east of Borneo. Balut Island is $180 \mathrm{~km}$ north of Indonesia, while Cape San Agustin is $200 \mathrm{~km}$ north. The four potential migration funnels (shaded grey) identified based on predicted migratory routes are also shown. (A) At eastern and central Luzon, a bottleneck passing along the Sierra Madre Mountains will allow birds to follow the longest mountain range in the country. (B) At the southwest of Luzon, an unavoidable $70 \mathrm{~km}$ over-water crossing exists between Mindoro and Palawan. (C) At the southwest of the Philippines, a bottleneck between Negros and Zamboanga del Norte includes a $50 \mathrm{~km}$ over-water crossing. (D) At the southeast of the Philippines, an unavoidable $20 \mathrm{~km}$ over-water crossing exists between Leyte and Surigao. 
grey-faced buzzards take particular migration routes, we used ArcGIS 10.2.2 [51] to create deterministic models of grey-faced buzzard autumn migratory routes across the Philippines. We completed this in three stages. First, we evaluated the "cost" of movement as a result of landscape features (i.e., costs induced by distances between stopover sites on land and costs induced by overwater travel) and weather conditions (i.e. costs induced by changes in wind direction) buzzards encounter as they migrate through the archipelago. These calculations were based on model input data and cost estimates described below.

Second, we used accumulated cost surface methods to determine likely routes buzzards use to reach logical exit points in the south of the country. In these models, the value of a grid cell represents the combined energetic and safety cost of moving from that grid cell to an exit point [52-54]. The four exit points we used were Balabac Island, Bongao Island, Balut Island, and Cape San Agustin in Mindanao Island (Figure 1). Each of these exit points are at a southernmost island tip and each is the closest point to either the island of Borneo (shared by the countries of Malaysia, Brunei and Indonesia) or other Indonesian islands. Finally, we evaluated characteristics of these potential movement trajectories to determine the shortest and least costly routes buzzards could follow to move from the northernmost tip of the Philippines (Batan Island) to each exit point.

We used 1-km resolution as the standard processing cell size for our models. Because this is close to the known winter home range size of the species, we assumed that this would reasonably represent the scale at which grey-faced buzzards use the landscape, especially during stopovers. We transformed all maps from a geographic coordinate system (WGS 1984) to a projected coordinate system (WGS 1984 UTM Zone 51N).

\section{Model Input Data}

We used land cover and climate data for Philippine terrestrial habitat and all surrounding marine habitat that were within $4^{\circ} \mathrm{N}$ (southernmost extent of latitude) to $22^{\circ} \mathrm{N}$ (northernmost latitude), and $116^{\circ} \mathrm{E}$ (westernmost longitude) to $128^{\circ} \mathrm{E}$ (easternmost longitude). Data sources are described below; all maps were scaled or resampled to a $1-\mathrm{km}$ grid cell size for modeling. Our Philippine boundary map was downloaded from the Global Administrative Areas website [55].

To describe land cover types that buzzards might encounter on migration, we used the Global
Land Cover (GLC) 2000 dataset which classified land cover in 17 categories [56]. Because greyfaced buzzards are known to use rice paddies as foraging habitat, we identified rice paddies as those GLC lands classified as "agriculture" that also were categorized as "rice fields" in a second, more specific data source on croplands [57].

To identify potential migration stopover sites for grey-faced buzzards, we followed a two-step process. First, we used ArcGIS to create binary maps for habitat type. Our binary map for rice fields identified all $1 \mathrm{~km}$ grid cells with rice fields as 1 , and all grid cells with other habitats as 0 . Similarly, our binary map for wooded areas identified all grid cells with closed-canopy forests, open-canopy forests or plantations as 1 , and all grid cells with other habitats as 0 .

We then used the 'Extract Raster Edge' tool of the Geospatial Modelling Environment [58] to identify rice fields adjacent to wooded areas, thought to be critical habitats for grey-faced buzzards $[49,59]$. We selected these areas because previous work [eg. 45,46,48] suggests that each 'edge' could be used as a stopover site. We identified $60,442 \mathrm{~km}^{2}$ of rice fields and $79,250 \mathrm{~km}^{2}$ of wooded areas resulting in 6,567 potential $1-\mathrm{km}^{2}$ stopover sites across the Philippines. Of these, 2,887 are in Luzon, 1,111 in the Visayas and 2,569 in Mindanao.

To identify areas that would involve overwater travel, we created a binary map identifying all grid cells of water bodies as 1 , and all landforms as 0 . To describe weather that buzzards may encounter on migration, we used wind data measured at $50 \mathrm{~m}$ above the surface of the earth from the month of October (the primary month of buzzard migration) and averaged over 22 years (1983-2005) [60].

\section{Calculating Movement Costs}

To evaluate the cost of moving between stopover sites, we computed the straight-line (Euclidian) distance between any given cell to the nearest $1-\mathrm{km}^{2}$ potential stopover site. In the resulting stopover distance cost map, each $1-\mathrm{km}^{2}$ cell had a stopover distance cost value ranging from 0 to $547 \mathrm{~km}$, with mean $130 \mathrm{~km}(\mathrm{SD}=121$ $\mathrm{km})$.

To evaluate the cost of moving in winds of different directions, we reclassified wind direction to make traveling in winds blowing from the north (tailwinds, $135^{\circ}-225^{\circ}$ ) $1.08 \mathrm{x}$ less costly than moving in crosswinds blowing from the northeast or the northwest (crossing tailwinds, $90^{\circ}-135^{\circ}$ 
and $225^{\circ}-270^{\circ}$ ) and $1.20 \mathrm{x}$ less costly than moving in crosswinds blowing from the southeast or southwest (crossing headwinds, $45^{\circ}-90^{\circ}$ ). Thus, each $\mathrm{km}$ traveled with crossing tailwinds was equivalent to traveling $1.08 \mathrm{~km}$ with tailwinds and each $\mathrm{km}$ traveled with crossing headwinds was equivalent to traveling $1.2 \mathrm{~km}$ with tailwinds. These hypothetical costs were based on estimates derived from wandering albatross (Diomedea exulans) heart rates when flying in different wind directions [61]. To our knowledge no similar data exist for grey-faced buzzards or for any other similarly behaving raptors of any type. In this analysis, costs over land and water are considered to be similar.

The cost of over-water travel for a soaring migrant like the grey-faced buzzard is low when wind conditions are favorable [i.e., with tailwinds; 20,21,62]. Under crosswinds or headwinds however, the safety costs increase to the point that birds may alter their route to avoid water crossing or to reduce time spent under unfavorable wind conditions [22,24]. To incorporate costs of water crossings with a crosswind or headwind, we reclassified our water dataset so that grey-faced buzzards would never travel over-water under crosswinds or headwinds. Thus, each $\mathrm{km}$ traveled over water under tailwind was equivalent to traveling $1 \mathrm{~km}$ over land under tailwind. Cost of traveling with a crossing tailwind over land was equivalent to traveling $1.08 \mathrm{~km}$ with tailwinds over land. The cost of traveling into a crossing headwind over land was equivalent to traveling $1.2 \mathrm{~km}$ with tailwinds over land.

\section{Determining Movement Possibilities and Optimum Paths}

To evaluate the potential costs and benefits of different buzzard migration routes, we calculated the effective distance (accumulated travel cost) of all possible paths from an exit point to every grid cell. We used the 'Cost Distance' tool in ArcGIS and assigned an exit point (the "source data" in the cost distance tool) and a gridded cost dataset (see below; the "cost raster" in the cost distance tool). Accumulated travel costs were stored in a cost distance dataset and a direction dataset.

To determine the optimum paths, we identified the paths with the shortest effective distance (least-costly) linking an exit point to the entry point. We used the 'Cost Path' tool in ArcGIS and assigned the buzzard's starting point (Batan; the "destination data" in the cost path tool) and the accumulated travel costs (the outputs from the cost distance tool; the "cost distance raster" in the cost path tool). The GIS then calculates an "optimum path" which is the least costly route relative to the exit point and to the cost dataset (the two inputs into the cost distance tool). The cumulative route cost is unitless and thus is directly comparable among different exit points that used the same gridded cost dataset. However, these route costs are not useful for comparing alternatives when gridded cost datasets are not identical.

To understand how routes may vary as a result of trade-offs buzzards face (research question \#1), we prepared different gridded cost datasets based on all possible combinations of our 3 parameters $(\mathrm{n}=20$ migratory routes). We combined cost datasets by multiplying base costs by the proportionate increase in costs. We could not consider over-water costs without incorporating wind and models that required over-water costs only were not considered. Our gridded cost datasets were based on the following:

- Cost of moving between stopover sites only ( $n=4$ migratory routes, one to each endpoint)

- Cost of wind direction only ( $n=4$ migratory routes)

- Combined costs of stopover distances and wind direction ([Stopover distances * Wind costs], $n=4$ migratory routes)

- Combined costs of wind direction and over-water travel ([Wind costs * Over-water costs], $n=4$ migratory routes)

- Combined costs of stopover distances, over-water travel and wind direction ([Wind costs * Over-water costs * Stopover distances], full model, $\mathrm{n}=4$ migratory routes)

We used descriptive statistics to evaluate the different characteristics (route length, distance between stopovers, over-water length, length with specific wind directions) of our 20 migratory routes. As a sensitivity analysis, we compared distance traveled (total distance, distance between stopovers, distance over water, distance with specific wind directions) across the entire range of possible costs. Finally, within each of the five alternatives above, we compared movement costs (unitless), to determine which exit point we expected would be used depending on the migration strategy the buzzards used (research question \#2). Movement cost is a better measure than distance traveled because it also captures 
Table 1. Characteristics of 20 modelled grey-faced buzzard autumn migratory routes leading to four logical exit points in the south of the Philippines. These routes were modelled using 5 different cost raster datasets: Stopover distances only; Wind costs only; Stopover distances * Wind costs; Wind costs * Over-water costs; and Wind costs * Over-water costs * Stopover distances.

\begin{tabular}{|c|c|c|c|c|c|c|c|c|}
\hline & \multirow{2}{*}{$\begin{array}{l}\text { Length, } \\
\text { km }\end{array}$} & \multirow{2}{*}{$\begin{array}{l}\text { No. of } \\
\text { stopovers }\end{array}$} & \multirow{2}{*}{$\begin{array}{c}\text { Ave. } \\
\text { distance } \\
\text { bet. } \\
\text { Stopovers }\end{array}$} & \multirow{2}{*}{$\begin{array}{c}\text { Length } \\
\text { over } \\
\text { water, \% }\end{array}$} & \multicolumn{3}{|c|}{$\begin{array}{l}\text { Wind direction, } \\
\text { Proportion of length, } \%\end{array}$} & \multirow{2}{*}{$\begin{array}{l}\text { Movement } \\
\text { cost, } \\
\text { cost unit }\end{array}$} \\
\hline & & & & & Tailwind & $\begin{array}{l}\text { Crossing } \\
\text { tailwind }\end{array}$ & $\begin{array}{l}\text { Crossing } \\
\text { headwind }\end{array}$ & \\
\hline \multicolumn{9}{|l|}{ Stopover distances } \\
\hline Balabac & 1,923 & 158 & 90.17 & 25 & 1 & 58 & 41 & $36,615,570$ \\
\hline Bongao & 2,527 & 239 & 90.17 & 29 & 15 & 50 & 35 & $49,192,170$ \\
\hline Balut & 2,408 & 270 & 39.90 & 21 & 0 & 64 & 36 & $33,832,480$ \\
\hline Cape San Agustin & 2,536 & 282 & 42.19 & 20 & 0 & 58 & 42 & $34,255,860$ \\
\hline \multicolumn{9}{|l|}{ Wind costs } \\
\hline Balabac & 1,582 & 0 & - & 99 & 0 & 93 & 7 & 1,730 \\
\hline Bongao & 1,798 & 1 & 898.95 & 83 & 28 & 38 & 34 & 1,945 \\
\hline Balut & 1,810 & 15 & 279.65 & 74 & 0 & 52 & 48 & 2,043 \\
\hline Cape San Agustin & 1,750 & 3 & 437.45 & 77 & 0 & 47 & 53 & 1,988 \\
\hline \multicolumn{9}{|c|}{ Stopover distances $*$ Wind costs } \\
\hline Balabac & 1,923 & 154 & 41.68 & 25 & 1 & 58 & 41 & 39,960 \\
\hline Bongao & 2,527 & 243 & 87.32 & 29 & 15 & 50 & 35 & 52,390 \\
\hline Balut & 2,410 & 270 & 39.90 & 21 & 0 & 63 & 37 & 37,056 \\
\hline Cape San Agustin & 2,535 & 283 & 42.06 & 20 & 0 & 58 & 42 & 37,544 \\
\hline \multicolumn{9}{|c|}{ Wind costs * Over-water costs } \\
\hline Balabac & 1,662 & 13 & 191.75 & 22 & 0 & 58 & 42 & 477,518 \\
\hline Bongao & 2,419 & 17 & 152.59 & 22 & 15 & 47 & 38 & 478,997 \\
\hline Balut & 1,981 & 24 & 163.75 & 13 & 0 & 43 & 57 & 428,461 \\
\hline Cape San Agustin & 1,900 & 18 & 198.87 & 13 & 0 & 40 & 60 & 412,047 \\
\hline \multicolumn{9}{|c|}{ Wind costs * Over-water costs * Stopover distances } \\
\hline Balabac & 2,011 & 158 & 47.08 & 18 & 1 & 56 & 43 & $28,870,950$ \\
\hline Bongao & 2,970 & 223 & 91.82 & 17 & 13 & 48 & 39 & $27,677,460$ \\
\hline Balut & 2,506 & 223 & 50.89 & 11 & 0 & 42 & 58 & $25,996,470$ \\
\hline Cape San Agustin & 2,335 & 211 & 43.51 & 11 & 0 & 39 & 61 & $25,888,830$ \\
\hline
\end{tabular}

energetic and safety costs along each route [63].

\section{Validation}

Because we did not have telemetry data from buzzards, to check the viability of our modeled routes, we compared our modeled migration routes to published $[64,65]$ citizenscience $[66,67]$, and personal (CBC unpublished data) observations of grey-faced buzzards during migration season $(\mathrm{n}=29$ individual observations). We assumed that if our migration routes reasonably represent buzzard migration, then observations of buzzards should be located closer to modeled migration routes than would random points. To test this assumption, we created a distribution map of the 29 "observation points" and 87 random points. We used the 'Near' tool in
ArcGIS to determine the distance of each of our observation and random points to each of our modeled route and we used a Mann-Whitney U-test to compare, for each of the 20 routes, distances from routes to observation and random points.

To test the effectiveness of the routes modeled for each of the 4 exit points, we used a Kruskal-Wallis test with a Nemenyi test for post-hoc analyses [68] to compare the average difference in observed and random point-to-route distances according to exit point. Finally, we used a Kruskal-Wallis test to test the effectiveness of each of the 5 cost datasets used in modeling our routes by comparing observed and random point-to-route distances according to cost dataset. All statistical analyses were conducted with $\mathrm{R}$ statistical software, using the 'stats' package ( $1 \mathrm{~m}$, wilcox.test, 

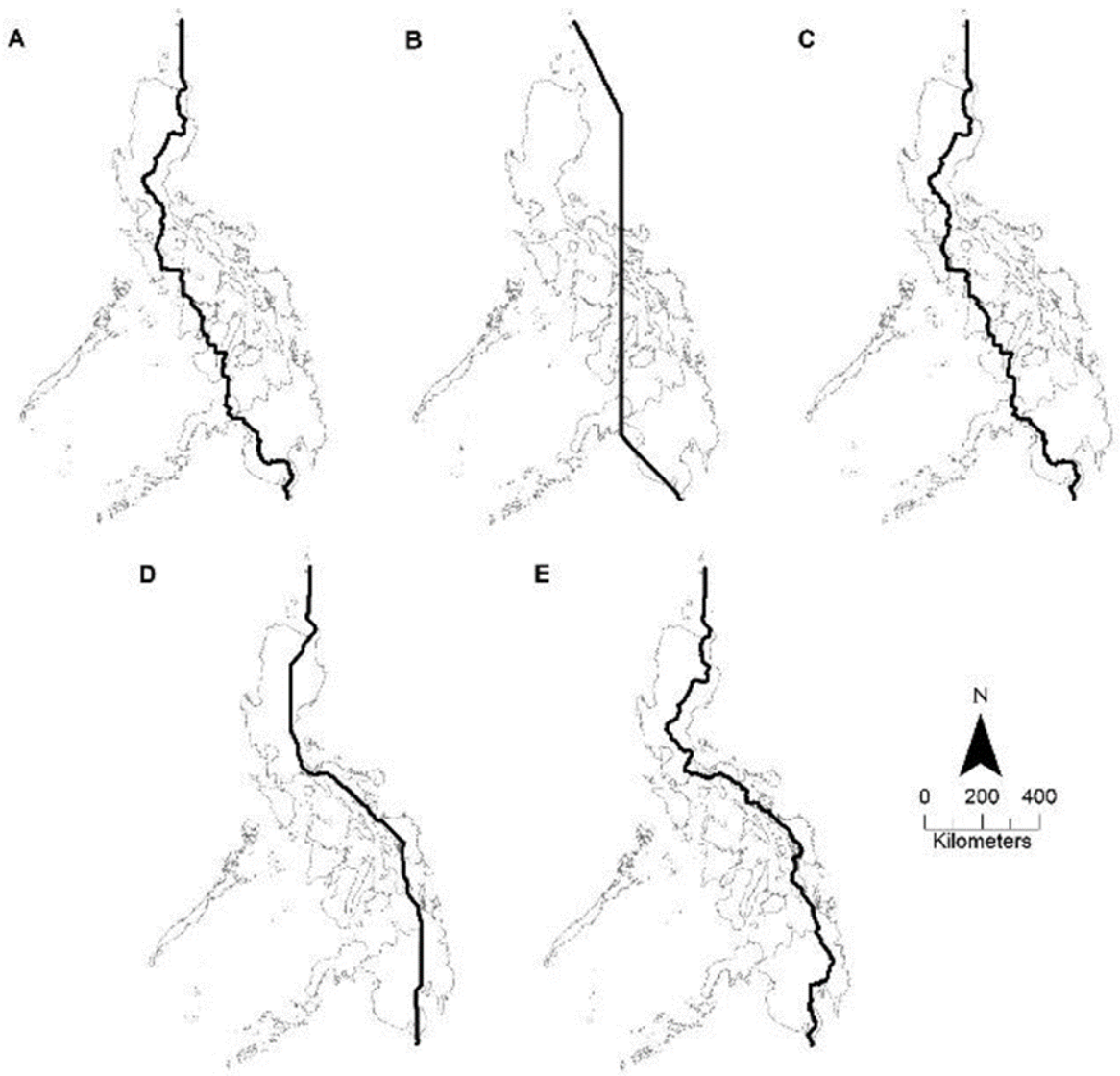

Figure 2. Migratory routes were modelled using 5 different cost of movement datasets. These routes, leading to Balut Island, for example, demonstrate trade-offs between response to external factors and were modelled using (A) costs of moving between stopover sites only $(2,408 \mathrm{~km})$; (B) cost of wind direction only $(1,810 \mathrm{~km})$; (C) combined costs of stopover distances and wind direction $(2,410 \mathrm{~km})$; (D) combined costs of wind direction and over-water travel $(1,981$ $\mathrm{km}$ ); and (E) combined costs of distances between stopover sites, costs of wind direction and over-water travel $(2,506 \mathrm{~km})$.

kruskal.test,) and 'PMCMR' package (posthoc. kruskal.nemenyi.test) [69].

\section{Results and Discussion}

\section{Route Variation and Trade-offs in Migratory Response}

Our 20 spatial models describe possible variation in migratory routes used by grey-faced buzzards moving across the Philippine archipelago in response to landscape parameters (stopover sites and water crossings) and weather conditions (wind direction, Table 1). These modeled routes allow us to examine the costs and consequences of different migratory responses in the case when migrants have to repeatedly decide between completing, delaying or foregoing over-water travel.

The modeled routes were between 1,582 and $2,970 \mathrm{~km}$ in length $(\bar{x}=2,176, \mathrm{SD}=373)$. There were between 0 and 282 stopovers ( $\bar{x}=140$, $\mathrm{SD}=112)$ on every route. On routes with more than one stopover, the distance between stopovers ranged from 40 to $899 \mathrm{~km}(\bar{x}=159, \mathrm{SD}=201)$. Over-water crossings accounted for 11 to $99 \%$ ( $\bar{x}=33 \%, \mathrm{SD}=26 \%$ ) of the total route length. Tailwinds were only present along some of the routes leading to Balabac and Bongao and occurred on 0 to $28 \%(\bar{x}=7 \%, \mathrm{SD}=9 \%)$ of the route length. Tailwinds were not encountered along any of the routes leading to Balut Island and Cape San Agustin. Crossing tailwinds were encountered along 38 to $93 \%$ ( $\bar{x}=53 \%, \mathrm{SD}=12 \%$ ) of the total route lengths, while crossing headwinds were encountered along 7 to $61 \%$ ( $\bar{x}=43 \%, \mathrm{SD}=12 \%$ ) of the route lengths.

If a modeled grey-faced buzzard was migrating to Balabac, it would always follow a route along eastern Philippines. However, if a modeled buzzard was migrating to Bongao, Balut Island or Cape San Agustin, it would either travel along a western route or an eastern route.

The general direction in which birds fly is 
believed to be either genetically inherited or culturally learned [70-72]. Avian migratory routes are then adjusted by each individual through continual assessment and reassessment of habitat and other factors they encounter [73,74]. The ideal migratory route is thought to be one that minimizes the costs of migration, as measured in terms of combinations of energy, time, or risk [14,75-77]. The resulting characteristics of these routes thus reflect the bird's assessment of the potential costs and benefits of each route over time [73].

Single-parameter models. A hypothetical grey-faced buzzard that tries to minimize distances between stopover sites to reach any of the logical exit points (Figure 2A) will travel along migratory routes that are up to $37 \%$ longer ( $\bar{x}=30 \%$ difference, $\mathrm{SD}=7 \%$ ) than the route of a buzzard minimizing only wind resistance (Figure 2B). However, such a buzzard will travel shorter distances between stopover sites ( $\bar{x}=159 \%$ fewer kilometers, $\mathrm{SD}=7 \%$ ) than a buzzard responding only to wind resistance. The most likely routes of travel for a buzzard minimizing distances between stopover sites to reach either Bongao, Balut Island or Cape San Agustin would involve travel along the western side of the country.

A hypothetical buzzard that tries to minimize wind resistance to reach any of the logical exit points (Figure 2B) will move along 'straighter' and shorter routes than a buzzard minimizing only stopover distances. Such a buzzard will travel along migratory routes with longer over-water crossings ( $\bar{x}=111 \%, \mathrm{SD}=9 \%$ ) than a buzzard responding only to stopover distances. A buzzard minimizing wind resistance to reach Balabac will not have any access to stopover sites. A buzzard minimizing wind resistance to reach either Balabac or Bongao would receive more wind assistance from tailwinds than a buzzard heading towards any other exit point.

Multiple-parameter models. A hypothetical grey-faced buzzard that attempts to minimize both distances between stopover sites and wind resistance to reach any of the logical exit points (Figure 2C) will travel along migratory routes that are up to $29 \%$ longer ( $\bar{x}=17 \%, \mathrm{SD}=9 \%$ ) than would a buzzard minimizing both wind resistance and over-water travel (Figure 2D). Such a buzzard would travel shorter distances between stopover sites $(\bar{x}=172 \%, \mathrm{SD}=4 \%)$ and encounter less resistance from northward crosswinds ( $\bar{x}=23 \%$, $\mathrm{SD}=17 \%$ ) than would a buzzard responding to both wind resistance and over-water travel. A buzzard minimizing both stopover distances and wind resistance to reach Bongao would receive more wind assistance from tailwinds than a buzzard heading towards any other exit point. A buzzard minimizing both stopover distances and wind resistance to reach either Bongao, Balut Island or Cape San Agustin would most likely migrate along the western part of the country.

A hypothetical buzzard that attempts to minimize both wind resistance and over-water travel (Figure 2D) will travel along straighter and shorter routes than a buzzard minimizing both stopover distances and wind resistance. Such a buzzard would travel along migratory routes with shorter over-water crossings $(\bar{x}=32 \%$, $\mathrm{SD}=12 \%$ ) than a buzzard responding to both stopover distances and wind resistance. A buzzard minimizing both stopover distances and wind resistance to reach Bongao would receive more wind assistance from tailwinds than a buzzard heading towards any other exit point. A buzzard minimizing both stopover distances and wind resistance to reach either Bongao, Balut Island or Cape San Agustin would migrate along the eastern side of the country.

A hypothetical buzzard that responds to minimizing stopover distances, over-water travel and wind resistance (Figure 2E) will travel along routes that are up to $16 \%$ shorter ( $\bar{x}=8 \%$, $\mathrm{SD}=5 \%$ ) than the route of a buzzard minimizing both stopover distances and wind resistance (Figure 2C) and routes that are up to 23\% longer ( $\bar{x}=21 \%, \mathrm{SD}=2 \%$ ) than the route of a buzzard minimizing both wind resistance and over-water travel (Figure 2D). Such a buzzard will travel longer distances between stopover sites ( $\bar{x}=11 \%$, $\mathrm{SD}=8 \%$ ) than a buzzard responding to stopover distances and wind resistance and travel shorter distances between stopover sites ( $\bar{x}=101 \%$, $\mathrm{SD}=32 \%$ ) than a buzzard responding to wind resistance and over-water travel. Such a buzzard will take shorter over-water crossings ( $\bar{x}=37 \%$, $\mathrm{SD}=18 \%)$ and encounter more resistance from crossing headwinds over land ( $\bar{x}=13 \%$, $\mathrm{SD}=16 \%$ ) than a buzzard responding to any other combination of parameters. A buzzard minimizing stopover distances, wind resistance and over-water travel to reach Bongao would receive more wind assistance from tailwinds than a buzzard heading towards any other exit point. A buzzard minimizing stopover distances, wind resistance and over-water travel to reach either Bongao, Balut Island or Cape San Agustin would migrate along the eastern side of the country.

The costs used to generate our models are 
almost certainly imprecise and it may be impossible to calculate the exact costs of these over-water flights. If our estimate of energy expenditure was high, then our models will suggest hypothetical buzzards performing more over-water crossings than actual grey-faced buzzards in migration. Similarly, if our estimate of energy expenditure was low, then our models will suggest longer migratory routes than the ones actual buzzards use when flying across the country.

In our models of migration through the Philippines, the cost of movement between potential stopover sites was the factor that had the most influence on the characteristics of the autumn migratory routes of grey-faced buzzards. In response to availability of stopover sites, a hypothetical buzzard not only shortened distances traveled between stopovers, it also had potential access to more stopover sites than would a buzzard following a different strategy. However, responding to stopovers resulted in migratory routes that were longer and more tortuous (less straight) than necessary $[25,78,79]$. For a buzzard behaving in this manner, an optimal migratory route therefore may be one that first maximizes opportunity for stopovers and secondarily minimizes distance traveled. The importance of stopover sites corresponds well with the known biology of the species. In fact, stopover sites have been found to be important to grey-faced buzzard
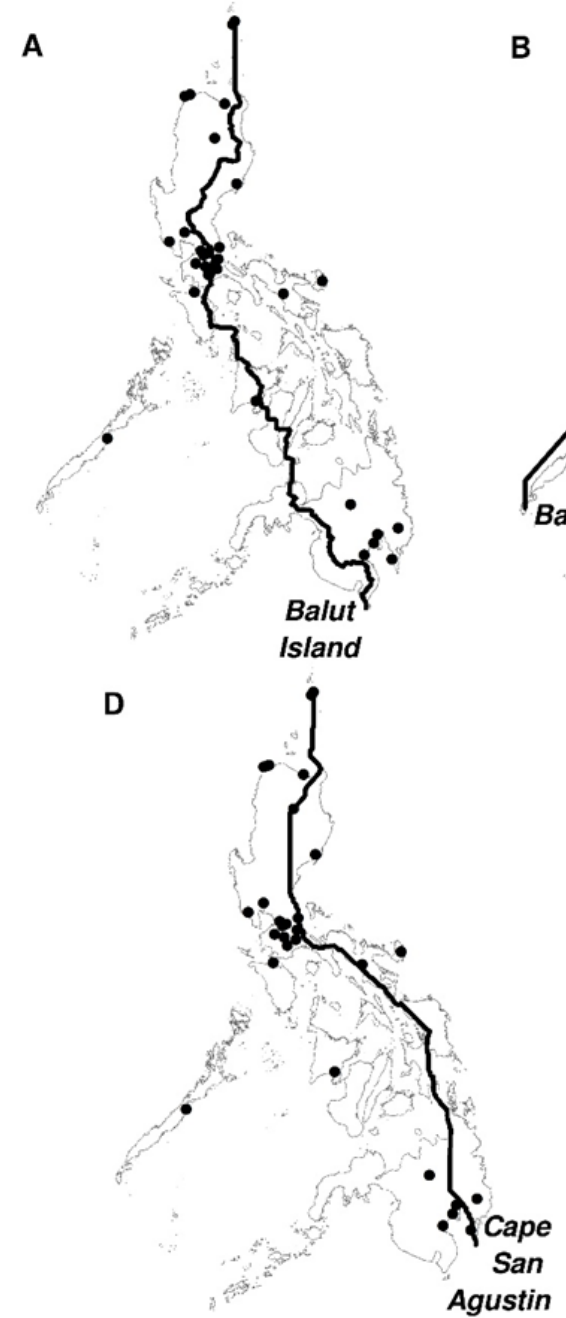

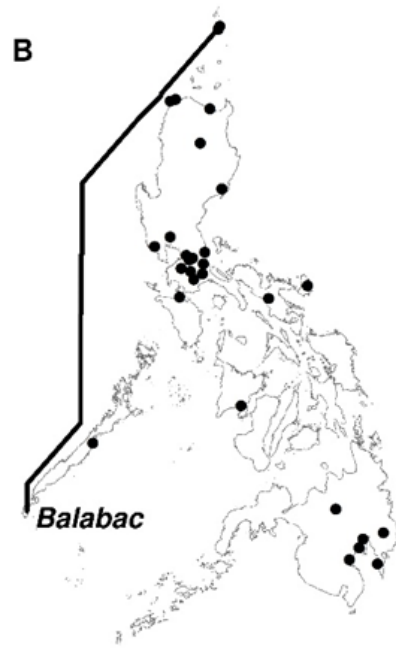

E

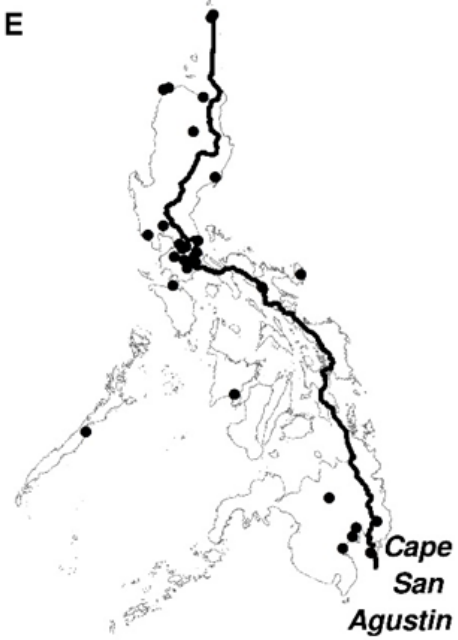

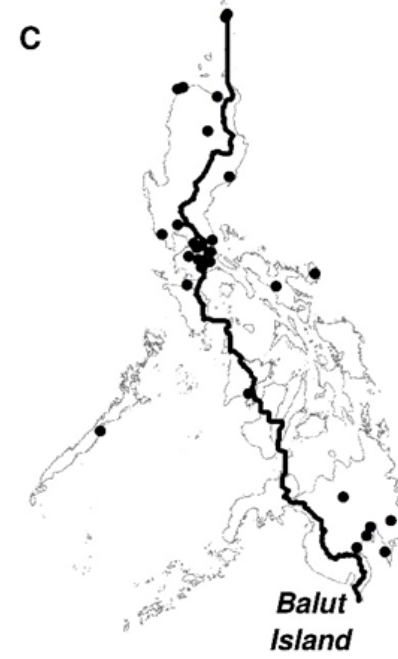

- Observation points

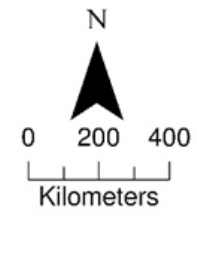

Figure 3. Most likely migratory routes depending on migration strategy buzzards use. The route with the cheapest movement cost (in cost units) among different exit points using the same gridded cost dataset was selected. (A) Stopover distances only; (B) Wind costs only; (C) Stopover distances x Wind costs; (D) Wind costs x Over-water costs; and (E) Wind costs $\mathrm{x}$ Over-water costs $\mathrm{x}$ Stopover distances. Also shown is the distribution of observation points ( $\bullet$ ) of grey-faced buzzards during migration. Observation points $(n=29)$ were compiled from published, citizen-science and personal data and illustrate how modeled routes correspond to observed buzzard behavior. 
migratory routes and buzzards exhibit high fidelity to some of these sites [42].

As grey-faced buzzards migrate, they complete long-distance, over-water travel [16]. However, after grey-faced buzzards enter the Philippine archipelago, they may still tend to select routes with fewer and shorter over-water crossings whenever possible $[16,42]$. Often, there are limited options to minimizing the safety costs of overwater travel (i.e., there is only one point in an island with the narrowest water crossing) and the routes of individual buzzards will geographically converge around a common, population-level route [80]. This makes unavoidable over-water crossings, such as those suggested between Mindoro and Palawan, Negros and Zamboanga del Norte and Leyte and Surigao, potentially important funnel points for grey-faced buzzard migration.
In our models of migration through the Philippines, minimizing the risks involved with over-water travel altered the geography or location of migratory routes. When trying to minimize overwater crossings, a hypothetical buzzard would travel through an eastern route to reach either Bongao, Balut Island or Cape San Agustin. A buzzard which does not respond to risk associated with over-water crossings would travel a western route to reach either of these three exit points. This is because eastern routes had greater distances with unfavorable, crossing headwinds over land than did a western route. This illustrates the broadly-based trade-offs migrants face in favoring minimizing the risks of traveling over-water under wind resistance over minimizing the energetic costs associated with unfavorable winds over land.

Table 2. Means and results of Mann-Whitney U tests to compare distances of 29 observation points and 87 random points to each of the 20 modelled migratory routes. These routes were modelled using 5 different cost raster datasets: Stopover distances only; Wind costs only; Stopover distances * Wind costs; Wind costs * Over-water costs; and Wind costs * Over-water costs * Stopover distances. (Significant p-values are bold)

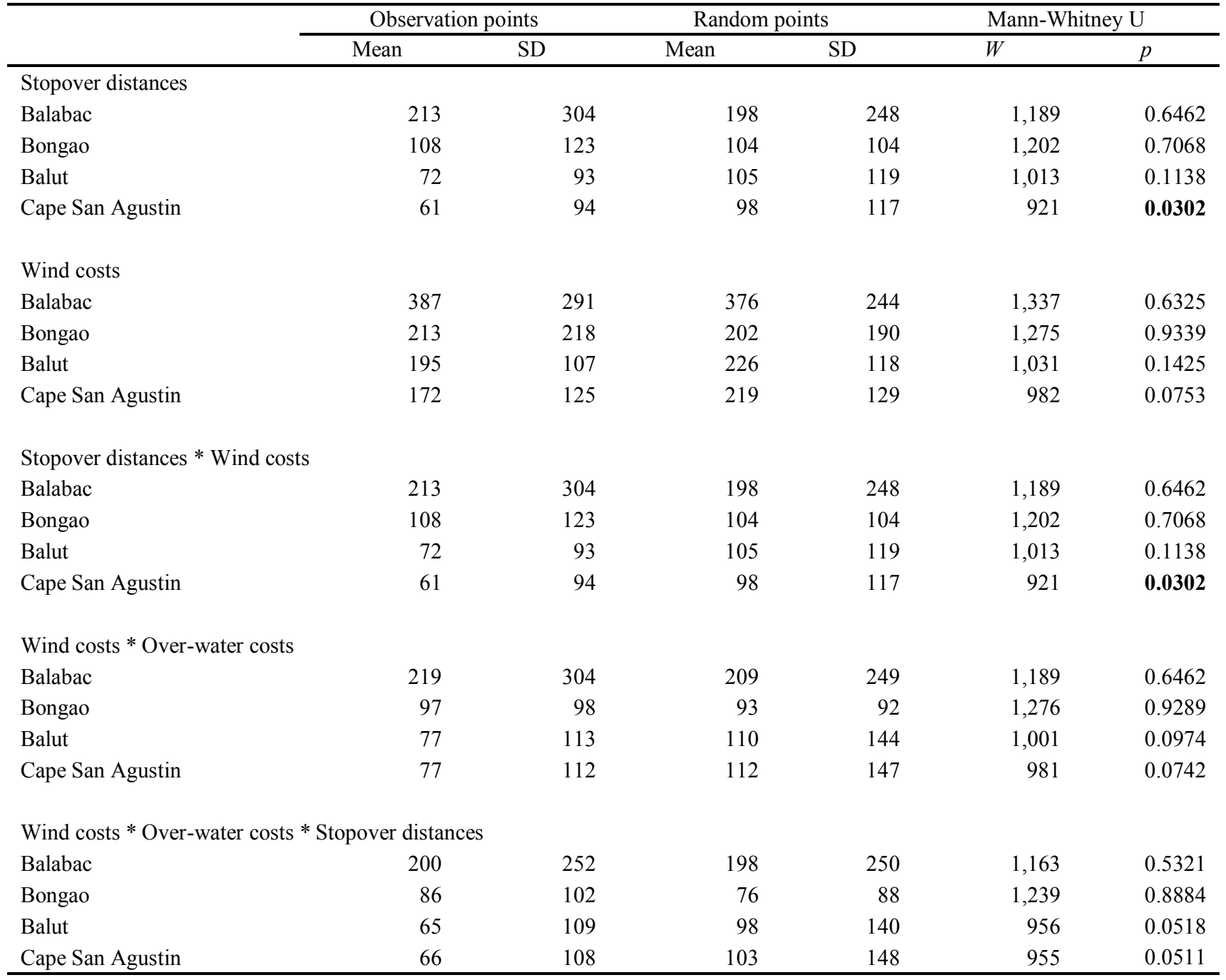


Finally, in our models of migration through the Philippines, minimizing the costs of wind resistance had the weakest influence on both the characteristics and geography of migratory routes. If minimizing wind resistance is the only goal, a hypothetical buzzard would travel a short and straight route. A buzzard flying along this low-cost migratory route would have limited access to key resources and face repeated open-water crossings.

\section{Possible Autumn Migratory Routes and Movement Funnels}

To identify how destinations influenced movement costs, we identified the least costly (in terms of movement costs) route alternatives from each of our gridded cost datasets. In each case, these comparisons were for each of the five sets of conditions laid out in the methods; this method does not allow us to compare costs from models that started with different cost datasets. One of our least costly routes led to Balabac (Wind costs only, Figure 3B), two led to Balut Island (Stopover distances only, Figure 3A; and Stopover distances * Wind costs, Figure 3C), and two led to Cape San Agustin (Wind costs * Over-water costs, Figure 3D; and Wind costs * Over-water costs * Stopover distances, Figure 3E).

We identified areas where our modeled routes overlapped or suggested relatively long and unavoidable over-water crossings. Sixteen out of our 20 modeled routes passed over eastern and central Luzon, along a leading line created by the Sierra Madre Mountains, the longest mountain range in the country (Figure 1A). At the southwest of Luzon, there is an unavoidable $70 \mathrm{~km}$ over-water crossing between Mindoro and Palawan (Figure 1B). Birds migrating to Palawan or exiting the country through Balabac would feed through this bottleneck. This crossing was in four of five routes leading to Balabac. At the southwest of the Philippines, there is a $50 \mathrm{~km}$ bottleneck over water between the islands of Negros and Zamboanga del Norte (Figure 1C). Birds wintering in Mindanao, or continuing on to presumed destinations in Borneo and Indonesia through Bongao, Balut Island or Cape San Agustin would encounter this water crossing. To reach this particular bottleneck, buzzards would have to island hop across western Visayas, involving over-water crossings ranging from 9 to $50 \mathrm{~km}$. This funnel was in 7 of the 15 modeled routes for Bongao, Balut Island and Cape San Agustin. Finally, at the southeastern part of the Philippines, there is an unavoidable $20 \mathrm{~km}$ overwater crossing between Leyte and Surigao (Figure
1D). Birds wintering in Mindanao, or continuing on to presumed destinations in Indonesia through Bongao, Balut Island or Cape San Agustin would be forced through this bottleneck. This water crossing was in six of the modeled routes leading to Bongao, Balut and Cape San Agustin.

\section{Model Validation}

Observation points and random points were not randomly distributed with regards to five routes modeled for the four exit points (Kruskal-Wallis, $\chi 2=16.303, \mathrm{df}=3, \mathrm{p}=0.001$ ). Post hoc tests showed that observation points were closer than random points to the modeled routes leading to Balut and Cape San Agustin than to routes leading to Balabac and Bongao (Figure 3). In addition, observation points were significantly closer than random points to two out of five modeled routes leading to Cape San Agustin (Table 2). Observation points and random points had similar distances to route alternatives (one for each exit point) modeled according to our five gridded cost datasets (Kruskal-Wallis, $\chi 2=0.3286, \mathrm{df}=6$, $\mathrm{p}=0.9879$ ).

Based on our model of migration through the Philippines, Balabac would be the most likely exit point for a buzzard that minimizes island hopping and wind resistance. Such a buzzard will have little to no opportunity for stopovers but will also migrate less distance from its entry point at Basco. A buzzard which began migration later in the season and feels pressure to minimize migration time may be most likely to behave this way. Although autumn migration has not yet been directly studied at Balabac, autumn migrants have been observed from research vessels traveling over the South China Sea between Balabac and Borneo $[81,82]$.

Our models suggest that Bongao is the least likely exit point used during autumn regardless of a buzzard's migration strategy. In fact, this prediction corresponds well with known migration patterns through Bongao. For example, Oriental honey-buzzards Pernis ptilorhyncus that winter in the Philippines are known to use Bongao as an entry point into the country during autumn migration and an exit point from the country during spring [83,84]. No honey-buzzards have been tracked using Bongao as an exit point in autumn.

Based on our model of migration through the Philippines, Balut Island is the most likely exit point for a buzzard that minimizes distances traveled between stopover sites and minimizes wind resistance. Such a buzzard would maximize 
opportunities for stopovers along a western route where wind resistance is less prevalent. A buzzard aiming to save energy in migration might behave this way as the wind conditions of a western route may facilitate migration. Autumn migration has not yet been directly studied in Balut Island although raptor migrants have been monitored about $20 \mathrm{~km}$ northwest of Balut Island [85] and in Sulawesi, Indonesia, almost $200 \mathrm{~km}$ south [86].

Finally, Cape San Agustin is the most likely exit point for a buzzard that minimizes distances traveled between stopover sites, minimizes wind resistance, and minimizes overwater crossings. Such a buzzard will maximize opportunities for stopovers along an eastern route where there are few over-water crossings between islands despite great wind resistance over land. A buzzard aiming to minimize risks from over-water travel might behave this way. There is evidence that this strategy is used and raptor migrants have been directly observed initiating autumn ocean crossings from Cape San Agustin, heading towards the direction of Sulawesi-Talaud (Indonesia) [87].

\section{Optimal Migration Strategy}

Field data supported our models better when routes were evaluated according to the exit point than when evaluated according to costs of movement. Although the rate of correspondence between these field data and modeled data was not strong, this is not unexpected given the nature of the field data available (there are no systematic studies of this problem and only a few anecdotal, often-unpublished, observations are reported in literature). Our modeled routes are similar to migration routes for a similarly sized Accipiter using the same flyway. Nevertheless, the two exit points that our models predict would be most used (Balut Island and Cape San Agustin) had the best correspondence to the validation data and are likely the most used routes by migrating raptors.

Examining specific migratory responses to each external factor allowed us to identify possible optimal migration strategies for grey-faced buzzards when navigating oceanic flyways through archipelagos. Our models suggest that the optimal migratory strategy for these birds is to find the shortest route to an exit point with the greatest possible access to stopover habitats and fewest open-water crossings under wind resistance. This strategy coincides with observations of grey-faced buzzards that migrated to the Philippines but wintered in the north of Luzon, instead of exiting the archipelago [23]. Therefore, an optimally migrating bird might not necessarily use the straightest and shortest routes (i.e., the modeled routes produced using only the cost of wind direction). In fact, these straightest and shortest routes seem unlikely pathways for experienced migrants. If experienced buzzards indeed maximize refueling opportunities at stopovers and minimize risks through fewer over-water crossings under wind resistance, they may generally be energy-minimizers during autumn migration across the Philippines. This hypothesis could be tested in two ways, one by evaluating if older, more experienced migrants indeed choose these routes, or two, by using telemetry to evaluate if birds conform more consistently with these modeled predictions as they gain experience.

Optimal migration strategies may vary by season. For example, if island crossings and wind conditions have a strong influence on spring migratory routes, grey-faced buzzards may be energy-minimizers during that season as well. In fact, the distribution of favorable winds are drastically different between seasons [88] and during spring, strong resistance from southward winds would intensify energetic and safety costs of crossing from Indonesian islands to the Philippines. To minimize energy expenditure and risk, migrants would have to avoid the Philippines during spring and fly northward following the East-Asian Continental Flyway. In fact, this is the strategy that Oriental Honey-buzzards use $[22,89]$. Using this route greatly reduces over-water travel and allows migrants to benefit from wind support and convective conditions over land. In contrast, grey-faced buzzards may be time minimizers during spring and return along the same route they traveled southbound. By doing this, the birds would expend energy compensating for southward winds but would save migration time by avoiding a huge detour around the South China Sea.

Tracking data of birds captured in Japan and migrating within Japanese islands indicates autumn and spring routes remain similar, although stopover sites used were different [42], suggesting that birds select for time minimization. Migration monitoring at the Indonesia island of Sangihe is similarly supportive of a time minimization hypothesis, revealing migrants regularly traveling over-water under heavy opposing winds in spring [86]. Likewise, spring migration counts conducted in the northern coast of Luzon also support this concept of time minimization via reverse migration [66], although less strongly than would tracking data from the Philippines. 


\section{Conclusion}

The spatial models we built assessed costs, consequences and potential migratory responses by grey-faced buzzards to external factors and provided insight into migratory strategies individual birds may select. These models also showed how migratory routes may vary as calculations for movement costs and targeted exit points changed and they provide insight into tradeoffs in migratory responses, potential exit points used according to migration strategy, and finally, potential optimal migration strategy of buzzards and other birds facing open-water crossings.

Our models suggest that the optimal migratory strategy for the grey-faced buzzards is to find the shortest route to an exit point with the greatest possible access to stopover habitats and fewest open-water crossings under wind resistance. Additionally, our models suggest that during autumn migration, Balut Island and Cape San Agustin are the two exit points most likely to be used by these birds.

Raptor migration on oceanic flyways in general, through the Philippines in particular, remains poorly understood. Our models of migration through the Philippines were derived from somewhat limited existing natural history information. Although relatively low in complexity, they allow us to better understand the potential trade-offs between the costs and consequences of migratory responses to landscape and weather conditions along an oceanic flyway. They also serve as an important foundation by producing specific and testable hypotheses about the evolution of this behavior in general and, specifically to the Philippines, about locations of potentially good count sites, about potential migration tracks of these birds, and about the distribution of exit points birds may use as they migrate across the Philippines.

\section{Acknowledgment}

This study was funded by the Project Soar Award of Hawk Mountain Sanctuary (USA) and The Sperry Fund Scholars in Raptor Conservation Science. We thank the Wild Bird Club of the Philippines for granting us permission to use bird records contributed by the following individuals and organizations: Adrian Constantino, Alex Tiongco, Amado Bajarias, Andy Mears, Arne Jensen, Bird Quest, Birdtour Asia, Carmela Balcazar, Cebu Biodiversity Conservation
Foundation, Cristina Cinco, Des Cambaliza, Desmond Allen, Eric Barnes, Felix Servita, Fergus Crystal, HARIBON Foundation, Philippines, Herman Nuytemans, Ipat Luna, Ivan Sarenas, James McCarthy, Jasmin Meren, Jayce Japlit, Jelaine Gan, John Mark de Leon, Jon Villasper, Karen Ochavo, Kitty Arce, Leny Ledesma, Lisa Marie Paguntalan, Marc Ameels, Marites Cervero, Mark Villa, Mark Wallbank, Mike Lu, Ned Livag, Nicky Icarangal, Nikki Dyanne Realubit, Paul Bourdin, Pete Simpson, Peter Stevens, Randy Weisser, Richard Ruiz, Sylvain Wamelink, Sylvia Ramos, Tim Fisher, Todd Pepper, Trinket Canlas, Vincent Lao, and Yannie Valmero. We also thank Brenden McNeil for suggestions on our modeling approach and Jinghong Lee for insights on greyfaced buzzard movements across the Philippines. Reviews by Petra Wood, Jim Anderson and Brenden McNeil improved the quality of the manuscript. This is Conservation Science Contribution number 326 from Hawk Mountain Sanctuary. Any use of trade, product, or firm names is for descriptive purposes only and does not imply endorsement by the U.S. Government.

\section{References}

[1] Newton, I. (2004) Population limitation in migrants. Ibis, 146, 197-226. doi:10.1111/j.1474919x.2004.00293.x.

[2] Newton, I. (1998) Population limitation in birds, Academic Press, Inc.

[3] Sillett, T.S. and Holmes, R.T. (2002) Variation in survivorship of a migratory songbird throughout its annual cycle. Journal of Animal Ecology 71, 296-308. doi:10.1046/j.1365-2656.2002.00599.x.

[4] Klaassen, R.H.G., Hake, M., Strandberg, R., Koks, B.J., Exo, K.M., Bairlein, F., Alerstam, T., Trierweiler, C., Exo, K.M., Bairlein, F., and Alerstam, T. (2014) When and where does mortality occur in migratory birds? Direct evidence from long-term satellite tracking of raptors. Journal of Animal Ecology 83, 176-184. doi:10.1111/13652656.12135.

[5] Oppel, S., Dobrev, V., Arkumarev, V., Saravia, V., Bounas, A., Kret, E., Velevski, M., Stoychev, S., and Nikolov, S.C. (2015) High juvenile mortality during migration in a declining population of a long-distance migratory raptor. Ibis 157, 545-557. doi:10.1111/ibi.12258. 
[6] Dale, C.A. and Leonard, M.L. (2011) Reproductive consequences of migration decisions by Ipswich Sparrows (Passerculus sandwichensis princeps). Canadian Journal of Zoology 89, 100 108. doi:10.1139/z10-098.

[7] Norris, D.R., Marra, P.P., Kyser, T.K., Sherry, T.W., and Ratcliffe, L.M. (2004) Tropical winter habitat limits reproductive success on the temperate breeding grounds in a migratory bird. Proceedings. Biological sciences / The Royal Society 271, 59-64. doi:10.1098/rspb.2003.2569.

[8] Norris, D.R. and Marra, P.P. (2007) Seasonal interactions, habitat quality, and population dynamics in migratory birds. The Condor 109, 535-547. doi:10.1650/8350.1.

[9] Sillett, T.S., Holmes, R.T., and Sherry, T.W. (2000) Impacts of a global climate cycle on population dynamics of a migratory songbird. Science 288, 2040-2042. doi:10.1126/science.288. 5473.2040 .

[10] Runge, M.C. and Marra, P.P. (2005) Modeling seasonal interactions in the population dynamics of migratory birds. In Birds of two worlds: The ecology and evolution of migration (Greenberg, R. and Marra, P. P., eds), pp. 375-390, John Hopkins University Press.

[11] Newton, I. (2006) Can conditions experienced during migration limit the population levels of birds? Journal of Ornithology 147, 146-166. doi:10.1007/s10336-006-0058-4.

[12] Alerstam, T. and Hedenström, A. (1998) The development of bird migration theory. Journal of Avian Biology 29, 343-369.

[13] Henningsson, S.S. and Alerstam, T. (2005) Barriers and distances as determinants for the evolution of bird migration links: the arctic shorebird system. Proceedings of the Royal Society B 272, 2251-2258. doi:10.1098/rspb.2005.3221.

[14] Alerstam, T., Hedenström, A., and Åkesson, S. (2003) Long-distance migration: evolution and determinants. Oikos 103, 247-260.

[15] Tucker, V.A. (1975) The energetic cost of moving about. American Scientist 63, 413-419.

[16] Bildstein,K.L. (2006) Migrating raptors of the world: Their ecology and conservation, Cornell University Press.

[17] Duerr, A.E., Miller, T. a., Lanzone, M., Brandes, D., Cooper, J., O’Malley, K., Maisonneuve, C., Tremblay, J., and Katzner, T. (2012) Testing an emerging paradigm in migration ecology shows surprising differences in efficiency between flight modes. PloS one 7, e35548. doi:10.1371/journal.pone.0035548.

[18] Mandel, J.T., Bildstein, K.L., Bohrer, G., and Winkler, D.W. (2008) Movement ecology of migration in turkey vultures. Proceedings of the National Academy of Sciences of the United States of America 105, 19102-19107. doi:10.1073/ pnas.0801789105.

[19] Kerlinger, P. (1989) Flight strategies of migrating hawks, University of Chicago Press.

[20] Meyer, S.K., Spaar, R., and Bruderer, B. (2000) To cross the sea or to follow the coast? Flight directions and behaviour of migrating raptors approaching the Mediterranean Sea in autumn. Behaviour 137, 379-399. doi:10.1163/ 156853900502132 .

[21] Liechti, F. (2006) Birds: Blowin' by the wind? Journal of Ornithology 147, 202-211. doi:10.1007/s10336-006-0061-9

[22] Nourani, E., Yamaguchi, N.M., Manda, A., and Higuchi, H. (2016) Wind conditions facilitate the seasonal water-crossing behaviour of Oriental Honey-buzzards Pernis ptilorhynchus over the East China Sea. Ibis 158, 506-518. doi:10.1111/ ibi. 12383

[23] Nourani, E., Safi, K., Yamaguchi, N.M., and Higuchi, H. (2018) Raptor migration in an oceanic flyway: Wind and geography shape the migratory route of grey-faced buzzards in East Asia. Royal Society Open Science 5, 171555. doi:10.1098/ rsos. 171555

[24] Bildstein, K.L., Bechard, M.J., Farmer, C., and Newcomb, L. (2009) Narrow sea crossings present major obstacles to migrating Griffon Vultures Gyps fulvus. Ibis 151, 382-391.

[25] Thorup, K., Alerstam, T., Hake, M., and Kjellén, N. (2003) Bird orientation: compensation for wind drift in migrating raptors is age dependent. 
Proceedings. Biological sciences / The Royal Society 270, S8-11. doi:10.1098/rsbl.2003.0014.

[26] Agostini, N. (2004) Additional observations of age-dependent migration behaviour in western honey buzzards Pernis apivorus. Journal of Avian Biology 35, 469-470. doi:10.1111/j.0908-8857. 2004.03450.x.

[27] Fagan, W.F., Lewis, M.A., Auger-Méthé, M., Avgar, T., Benhamou, S., Breed, G., Ladage, L., Schlägel, U.E., Tang, W.W., Papastamatiou, Y.P., Forester, J., and Mueller, T. (2013) Spatial memory and animal movement. Ecology Letters 16, 13161329. doi:10.1111/ele.12165.

[28] Harel, R., Horvitz, N., and Nathan, R. (2016) Adult vultures outperform juveniles in challenging thermal soaring conditions. Scientific Reports 6, 27865. doi:10.1038/srep27865.

[29] Crysler, Z.J., Ronconi, R.A., and Taylor, P.D. (2016) Differential fall migratory routes of adult and juvenile Ipswich Sparrows (Passerculus sandwichensis princeps). Movement Ecology 4, 3. doi:10.1186/s40462-016-0067-8.

[30] Mellone, U., Limiñana, R., Mallia, E., and Urios, V. (2011) Extremely detoured migration in an inexperienced bird: interplay of transport costs and social interactions. Journal of Avian Biology 42, 468-472. doi:10.1111/j.1600-048x. 2011.05454.x.

[31] Alerstam, T. (1979) Wind as selective agent in bird migration. Ornis Scandinavica 10, 76-93.

[32] Meyer, S.K., Spaar, R., and Bruderer, B. (2003) Sea crossing behaviour of falcons and harriers at the southern Mediterranean coast of Spain. Avian Science 3, 153-162.

[33] López-López, P., Limiñana, R., Mellone, U., and Urios, V. (2010) From the Mediterranean Sea to Madagascar: Are there ecological barriers for the long-distance migrant Eleonora's falcon? Landscape Ecology 25, 803-813. doi:10.1007/ s10980-010-9460-7.

[34] Gill, R.E., Tibbitts, T.L., Douglas, D.C., Handel, C.M., Mulcahy, D.M., Gottschalck, J.C., Warnock, N., McCaffery, B.J., Battley, P.F., and Piersma, T. (2009) Extreme endurance flights by landbirds crossing the Pacific Ocean: Ecological corridor rather than barrier? Proceedings of the Royal Society B: Biological Sciences 276, 447-57. doi:10.1098/rspb.2008.1142.

[35] Lin, W.H. and Severinghaus, L.L. (1998) Raptor migration and conservation in Taiwan. In Holarctic birds of prey (Chancellor, R. D. et al., eds), pp. 631-639, ADENEX and World Working Group of Birds of Prey.

[36] Ferguson-Lees, J. and Christie, D.A. (2001) Raptors of the world, Houghton Mifflin Company.

[37] Catibog-Sinha, C. and Heaney, L.R. (2006) Philippine biodiversity: Principles and practice, Haribon Foundation for the Conservation of Natural Resources, Inc.

[38] Ramage, C.S. (1968) Role of a tropical "Maritime Continent" in the atmospheric circulation 1. Monthly Weather Review 96, 365-370. doi:10.1175/1520-0493(1968)096<0365: roatmc $>2.0 . c 0 ; 2$.

[39] Saha, K. (2010) Tropical circulation systems and monsoons, Springer-Verlag.

[40] Chang, C.P., Harr, P.A., McBride, J., and Hsu, H.-H. (2004) The Maritime Continent monsoon. In East Asian monsoon (Chang, C. P., ed), pp. 107150, World Scientific Publishing

[41] PIDS (2005) Basics on Philippine climatology. Economic Issue of the Day 5

[42] Shiu, H.-J., Tokita, K., Morishita, E., Hiraoka, E., Wu, Y., Nakamura, H., and Higuchi, H. (2006) Route and site fidelity of two migratory raptors: Grey-faced Buzzards Butastur indicus and Honey-buzzards Pernis apivorus. Ornithological Science 5, 151-156. doi:10.2326/1347-0558(2006) $5[151:$ rasfot $] 2.0 . c 0 ; 2$

[43] Gamauf, A., Preleuthner, M., and Winkler, H. (1998) Philippine birds of prey: Interrelations among habitat, morphology, and behavior. The Auk $75,713-726$.

[44] Sakai, S., Yamaguchi, N., Momose, H., and Higuchi, H. (2011) Seasonal shifts in foraging site and prey of grey-faced buzzards (Butastur indicus), breeding in Satoyama habitat of Central Japan. Ornithological Science 10, 51-60. 
[45] Matsuura, T., Yokohair, M., and Azuma, A. (2005) Identification of potential habitats of grayfaced buzzard in Yatsu landscapes by using digital elevation model and digitized vegetation data. Landscape and Urban Planning 70, 231-243.

[46] Wu, Y., Fujita, G., and Higuchi, H. (2006) What landscape elements are correlated with the distribution of wintering Grey-faced Buzzards Butastur indicus in the Sakishima Islands, southwestern Japan? Ornithological Science 5, 157 -163 .

[47] Kadowaki, S., Murayama, T., and Kojima, Y. (2007) Differences in utilization of cultivated and uncultivated paddy fields as hunting grounds by the grey-faced buzzard-eagle, Butastur indicus. Journal of Yamashina Institue for Ornithology 39, 19-26.

[48] Momose, H., Ueta, M., Fujiwara, N., Uchiyama, T., Ishizaka, T., Morisaki, K., and Matsue, M. (2005) Factors affecting the number of breeding grey-faced buzzard-eagles Butastur indicus. Journal of the Japanese Institute of Landscape Architects 68, 555-558.

[49] Kawakami, K. and Higuchi, H. (2003) Population trend estimation of three threatened bird species in Japanese rural forests: the Japanese Night-Heron Gorsachius goisagi, Goshawk Accipiter gentilis and Grey-faced Buzzard Butastur indicus. Journal of the Yamashina Institute for Ornithology 35, 19-29.

[50] Ueta, M., Kurosawa, R., and Matsuno, H. (2006) Habitat loss and the decline of Grey-faced buzzards (Butastur indicus) in Tokyo, Japan. Journal of Raptor Research 40, 52-56.

[51] ESRI (2016) ArcGIS Desktop: Release 10.3.1, Environmental Systems Research Institute.

[52] Eastman, J.R. (1989), Pushbroom algorithms for calculating distances in raster grids in Proceedings of the 9th International Symposium on Computer Assisted Cartography, Autocarto 9, pp. 288-297

[53] Douglas, D.H. (1994) Least-cost path in GIS using an accumulated cost surface and slopelines. Cartographica 31, 37-51.

[54] Collischonn, W. and Pilar, J.V. (2000) A direction dependent least-cost-path algorithm for roads and canals. International Journal of Geographical Information Science 14, 397-406. doi:10.1080/13658810050024304

[55] GADM (2011), Global Administrative Areas: Philippines.

[56] GLC (2003), Global Land Cover 2000 database.

[57] Ellis, E.C., Klein Goldewijk, K., Siebert, S., Lightman, D., and Ramankutty, N. (2010) Anthropogenic transformation of the biomes, 1700 to 2000. Global Ecology and Biogeography 19, 589-606.

[58] Beyer, H.L. Geospatial modelling environment (Version 0.7.3.3) (2012) , http:// www.spatialecology.com/gme.

[59] Ueta, M., Kurosawa, R., and Matsuno, H. (2006) Habitat loss and the decline of Grey-faced Buzzards (Butastur indicus). Journal of Raptor Research 40, 52-56.

[60] Stackhouse Jr., P.W. (2013), NASA: Surface meteorology and solar energy (release 6.0).

[61] Weimerskirch, H., Guionnet, T., Martin, J., Shaffer, S.A., and Costa, D.P. (2000) Fast and fuel efficient? Optimal use of wind by flying albatrosses. Proceedings of the Royal Society of London Series B, Biological Sciences 267, 1869 1874. doi:10.1098/rspb.2000.1223

[62] Panuccio, M., Barboutis, C., Chiantante, G., Evangelidis, A., and Agostini, N. (2016) Pushed by increasing air temperature and tailwind speed: Weather selectivity of raptors migrating across the Aegean Sea. Ornis Fennica 93, 159-171.

[63] Etherington, T.R. and Holland, E.P. (2013) Least-cost path length versus accumulated-cost as connectivity measures. Landscape Ecology 28, 1223-1229. doi:10.1007/s10980-013-9880-2.

[64] McClure, H.E. (1998) Migration and survival of the birds of Asia, Revised Ed. White Lotus Press.

[65] McClure, H.E. (1974) Migration and survival of the birds of Asia, U.S. Army Medical Component, SEATO Medical Project. 
[66] Wild Bird Club of the Philippines (2015), Bird records, 2003-2013. .

[67] eBird (2012) eBird Basic Dataset. Version: EBD_relNov-2015, Nov 2015. Cornell Lab of Ornithology.

[68] Nemenyi, P. (1969) Variances: An elementary proof and a nearly distribution-free test. The American Statistician 23, 35-37.

[69] R Development Core Team (2013) , R: $A$ language and environment for statistical computing., $\mathrm{R}$ Foundation for Statistical Computing.

[70] Berthold, P., Helbig, A.J., Mohr, G., and Querner, U. (1992) Rapid microevolution of migratory behaviour in a wild bird species. Nature 2, 173-179. doi:10.1038/360668a0.

[71] Sutherland, W.J. (1998) Evidence for flexibility and constraint in migration systems. Journal of Avian Biology 29, 441-446. doi:10.2307/3677163.

[72] Gschweng, M., Kalko, E.K. V., Querner, U., Fiedler, W., and Berthold, P. (2008) All across Africa: highly individual migration routes of Eleonora's falcon. Proceedings of the Royal Society B-Biological Sciences 275, 2887-2896. doi:10.1098/rspb.2008.0575.

[73] Hutto, R.L. (1985) Habitat selection by nonbreeding, migratory land birds. In Habitat Selection in Birds (Cody, M. L., ed), pp. 455-476, Academic Press, Inc.

[74] Vardanis, Y., Klaassen, R.H.G., Strandberg, R., and Alerstam, T. (2011) Individuality in bird migration: routes and timing. Biology Letters 7, 502-5. doi:10.1098/rsbl.2010.1180.

[75] Hedenström, A. and Alerstam, T. (1997) Optimum fuel loads in migratory birds: Distinguishing between time and energy minimization. Journal of Theoretical Biology 189, 227-234. doi:10.1006/jtbi.1997.0505.

[76] Liechti, F. and Bruderer, B. (1998) The relevance of wind for optimal migration theory. Journal of Avian Biology 29, 561-568.

[77] Alerstam, T. (2011) Optimal bird migration revisited. Journal of Ornithology 152, 5-23. doi:10.1007/s10336-011-0694-1.

[78] González-Solís, J., Felicísimo, A., Fox, J.W., Afanasyev, V., Kolbeinsson, Y., and Muñoz, J. (2009) Influence of sea surface winds on shearwater migration detours. Marine Ecology Progress Series 391, 221-230. doi:10.3354/ meps08128.

[79] Hake, M., Kjellen, N., and Alerstam, T. (2003) Age-dependent migration strategy in honey buzzards Pernis apivorus tracked by satellite. Oikos 103, 385-396. doi:10.1034/j.1600-0706.2003. 12145.x.

[80] La Sorte, F.A., Fink, D., Hochachka, W.M., and Kelling, S. (2016) Convergence of broad-scale migration strategies in terrestrial birds. Proceedings of the Royal Society B 283, 20152588. doi:10.1098/rspb.2015.2588.

[81] Ellis, D.H., Kepler, A.K., and Kepler, C.B. (1990) Evidence for a fall raptor migration pathway across the South China Sea. Journal of Raptor Research 24, 12-18.

[82] Simpson, D.M. (1983) Autumn migration of landbirds off North Borneo in 1981. Sea Swallow $32,48-53$.

[83] Higuchi, H., Shiu, H., Nakamura, H., Uematsu, A., and Kuno, K. (2005) Migration of Honey-buzzards Pernis apivorus based on satellite tracking. Ornithological Science 4, 109-115.

[84] Yamaguchi, N., Tokita, K.-I., Uematsu, a., Kuno, K., Saeki, M., Hiraoka, E., Uchida, K., Hotta, M., Nakayama, F., Takahashi, M., Nakamura, H., and Higuchi, H. (2008) The large-scale detoured migration route and the shifting pattern of migration in Oriental honey-buzzards breeding in Japan. Journal of Zoology 276, 54-62. doi:10.1111/j.1469-7998. 2008.00466.x

[85] Tiongco, A., Cervero, M.T.A., Constantino, A.M., and Constantino, M.K.C. (2014) Project Southern Crossing 2014: First observations of autumn raptor migration at Sarangani, Mindanao, Philippines. Birding ASIA 24, 96-103.

[86] Germi, F., Young, G.S., Salim, A., Pangimangen, W., and Schellekens, M. (2009) 
Over-ocean raptor migration in a monsoon regime: spring and autumn 2007 on Sangihe, North Sulawesi, Indonesia. Forktail 25, 104-116.

[87] Concepcion, C.B., Dumandan, P.T., Silvosa, M.R., Bildstein, K.L., and Katzner, T.E. (2017) Species composition, timing and meteorological correlates of autumn open-water crossings by raptors migrating along the East-Asian Oceanic Flyway. Journal of Raptor Research 51, 25-37.
[88] Wyrtki, K. and Meyers, G. (1975) The trade winds over the Pacific Ocean. Journal of Applied Meteorology 15, 698-704.

[89] Yamaguchi, N.M., Arisawa, Y., Shimada, Y., and Higuchi, H. (2011) Real-time weather analysis reveals the adaptability of direct sea-crossing by raptors. Journal of Ethology 30, 1-10. doi:10.1007/s10164-011-0301-1 